Intecoms: Journal of Information Technology and Computer Science

Volume 1 Nomor 2, Desember 2018

e-ISSN : 2614-1574

p-ISSN : 2621-3249

DOI : https://doi.org/10.31539/intecoms.v1i2.302

\title{
SISTEM PAKAR BERBASIS WEB MENGGUNAKAN METODE BACKWARD CHAINING UNTUK MENENTUKAN NUTRISI YANG TEPAT BAGI IBU HAMIL
}

\section{WEB-BASED EXPERT SYSTEM USING BACKWARD CHAINING METHOD FOR DETERMINING THE RIGHT NUTRITION FOR PREGNANT WOMAN}

\author{
Yuvi Darmayunata \\ Universitas Lancang Kuning \\ yuvidarmayunata@unilak.ac.id
}

\begin{abstract}
Expert System is a computer-based system that uses knowledge, facts and reasoning techniques in solving problems that normally can only be solved by an expert in the field. Many cases can be used as research in Expert Systems, one diagnosis of proper nutrition. In this study we will design an expert system to diagnose the type of proper nutrition for pregnant women. Determining the proper nutrition for pregnant women is important to note because it causes birth defects and infant mortality. In this study, the system uses the Backward Chaining method in determining the proper nutrition for pregnant women. This system can provide the right solution for pregnant women. This application is made to the programming language PHP and MySQL as its knowledge base storage. System testing is done by matching the search process Backward Chaining in the decision tree to determine the proper nutrition for pregnant women at the design stage to the actual system that has been built.
\end{abstract}

Keywords : Expert System, diagnose, Backward Chaining, Nutrition, Pregnancy

\section{ABSTRAK}

Sistem Pakar adalah sistem berbasis komputer yang menggunakan pengetahuan, fakta, dan teknik penalaran dalam memecahkan masalah yang biasanya hanya dapat dipecahkan oleh seorang pakar dalam bidang tersebut. Banyak kasus yang bisa dijadikan penelitian dalam Sistem Pakar, salah satunya diagnosa nutrisi yang tepat. Pada penelitian ini akan dirancang suatu Sistem Pakar yang dapat mendiagnosis jenis nutrisi yang tepat bagi ibu hamil. Menentukan nutrisi yang tepat bagi ibu hamil penting untuk diketahui karena penyebab kematian dan lahir cacat bayi. Pada penelitian ini, sistem menggunakan metode Backward Chaining dalam menentukan nutrisi yang tepat bagi ibu hamil. Sistem ini dapat memberikan solusi yang tepat bagi ibu hamil. Aplikasi ini dibuat dengan bahasa pemrograman PHP dan MySQL sebagai penyimpanan basis pengetahuannya. Pengujian sistem ini dilakukan dengan mencocokkan proses Backward Chaining pada penelusuran pohon keputusan untuk menentukan nutrisi yang tepat bagi ibu hamil pada tahap perancangan dengan sistem sesungguhnya yang telah dibangun

Kata Kunci: Sistem Pakar, Diagnosa, Backward Chaining, Nutrisi, Hamil

\section{PENDAHULUAN}

Seiring perkembangan teknologi, dikembangkan pula suatu sistem teknologi yang mampu mengadopsi proses dan cara berpikir manusia yaitu teknologi Artificial Intelligence atau Kecerdasan Buatan. Kecerdasan buatan atau artificial intelligence merupakan bagian dari ilmu komputer yang membuat agar mesin (komputer) dapat melakukan pekerjaan seperti dan sebaik yang dilakukan oleh manusia. Artificial Intelliegence adalah kecerdasan buatan untuk memecahkan masalah tertentu yang juga disebut sebagai sistem berbasis pengetahuan. Sistem berbasis pengetahuan mencakup tugas, domain tugas dan pengetahuan engineer untuk mewakili pengetahuan yang tepat. Terjemahan pengetahuan berfokus pada desain terjemahan komputer yang menangkap informasi dan dapat 
digunakan untuk memecahkan masalah yang sulit dan kompleks (Bahl \&Kapoor, 2016). Sistem cerdas (intelligent system) adalah sistem yang dibangun dengan menggunakan teknikteknik artificial intelligence (Juriwansyah, 2014). Sistem Pakar adalah sistem berbasis komputer yang menggunakan pengetahuan, fakta, dan teknik penalaran dalam memecahkan masalah yang biasanya hanya dapat dipecahkan oleh seorang pakar dalam bidang tertentu. Sistem pakar memberikan nilai tambah pada teknologi untuk membantu dalam menangani era informasi yang semakin canggih (Tarigan, 2014).

Sistem Pakar merupakan salah satu bagian dari Kecerdasan Buatan yang mengandung pengetahuan dan pengalaman yang dimasukkan oleh satu atau banyak pakar ke dalam suatu area pengetahuan tertentu, sehingga setiap orang dapat menggunakannya untuk memecahkan berbagai masalah yang bersifat spesifik.

Dalam penelusuran ini menggunakan metode penalaran runut balik (Backward Chaining). Dalam runut balik penalaran dimulai dari konsekuen ke anteseden. Runut balik bekerja secara Backward untuk mendapatkan fakta-fakta yang mendukung hipotesa (Mukhtar \& Samsudin, 2014). Pada penelusuran ini menggunakan metode Depth First Search yang akan melakukan penelusuran kaidah secara mendalam dari simpul akar bergerak menurun ke tingkat dalam yang berurutan (Iriani, 2015). Runut balik (Backward Chaining) merupakan strategi pencarian yang arahnya kebalikan dari runut maju (Forward Chaining). Proses pencarian dimulai dari tujuan, yaitu kesimpulan yang menjadi solusi permasalahan yang dihadapi. Mesin inferensi mencari kaidah kaidah dalam basis pengetahuan yang kesimpulannya merupakan solusi yang ingin dicapai, kemudian dari kaidah kaidah yang diperoleh, masingmasing kesimpulan dirunut balik jalur yang mengarah ke kesimpulan tersebut (Tarigan, 2014; Al-Ajlan, 2015).

Kehamilan adalah fenomena alam dimana wanita hamil menghadapi banyak perubahan fisik dan emosional internal termasuk untuk mendukung jaringan sebagai pertumbuhan plasenta, komposisi darah yang berubah, peningkatan volume darah dengan volume plasma sekitar $1500 \mathrm{ml}$ dalam 34 minggu, juga massa sel darah merah meningkat sekitar 200-250 ml dan peningkatan tersebut lebih besar ketika suplemen zat besi tambahan diberikan, kapasitas untuk transportasi oksigen dinaikkan dengan peningkatan massa sel darah merah, musim gugur ini mungkin sebagian disebabkan oleh peningkatan filtrasi glomerulus yang menyebabkan peningkatan ekskresi beberapa asam amino, beberapa vitamin dan mineral (Elhissi, Sakka, Mazen., and Al-Khodari, 2012). Pada penelitian Indrawati dan Putranto tahun 2011 merancang sistem pakar untuk ibu hamil berbasis web untuk mengetahui pemenuhan gizi nya.

Status gizi merupakan aspek penting dari kesehatan dan kesehatan sebelum dan selama kehamilan. Di bawah gizi, perempuan memberikan kontribusi $20 \%$ dari kematian ibu, dan merupakan faktor risiko yang signifikan untuk bayi lahir mati, kelahiran prematur, kecil untuk usia kehamilan dan jumlah bayi berat lahir rendah. Namun disebagian besar negara 10-20\% dari wanita yang kurus. Perawakan pendek ibu mempertinggi risiko terhalang tenaga kerja, fistula obstetri dan kematian ibu, Hasil gadis yang terhambat sejak kecil. Hamil obesitas (kelebihan berat badan) dan telah dikaitkan dengan dua penyebab utama 
kematian ibu, hipertensi dalam kehamilan dan kehamilan diabetes mellitus, serta seluruh spektrum hasil kehamilan yang merugikan, termasuk praktek menyusui yang buruk. Terkait anestesi komplikasi, kehamilan berkepanjangan, infeksi morbiditas ibu. Kehamilan obesitas merupakan penyebab bayi lahir mati, kematian janin dan neonatal, dan terlebih lagi, melanggengkan epidemi obesitas karena anak-anak perempuan lebih mungkin untuk menjadi gemuk (Dean dkk, 2014). Nutrisi memainkan peran utama dalam kesehatan ibu dan anak. Status gizi ibu yang buruk terkait dengan hasil kelahiran yang merugikan. Namun, hubungan antara gizi ibu dan hasil kelahiran yang kompleks dan dipengaruhi oleh banyak faktor biologis, sosial ekonomi, dan faktor demografi, yang bervariasi dalam populasi yang berbeda. Memahami hubungan antara gizi dan kelahiran hasil ibu dapat memberikan dasar untuk mengembangkan intervensi gizi yang akan meningkatkan hasil kelahiran dan kualitas jangka panjang hidup dan mengurangi angka kematian, angka kesakitan, dan biaya perawatan kesehatan. Pada penelitian sebelumnya yaitu Cantika dkk (2016) menggunakan metode backward chaining untuk menentukan sistem komposisi nutrisi paka sapi.

\section{METODE PENELITIAN}

Pada tahap metodologi penelitian ini, penulis menggambarkan alur dari masing-masing langkah dalam penyusunan penelitian ini dari awal hingga akhir informasi yang didapatkan. Agar hasilnya bisa maksimal, tentunya harus mengikuti kaidah-kaidah (metode) yang telah ditetapkan. Metode penelitian ini memuat tentang kerangka kerja penelitian yang akan dibahas di bawah ini.
Pada penelitian ini akan dibahas metodologi penelitian untuk mengidentifikasi permasalahan, analisa permasalahan dan pada akhirnya mencari penyelesaian masalah di dalam menentukan nutrisi yang tepat bagi ibu hamil.

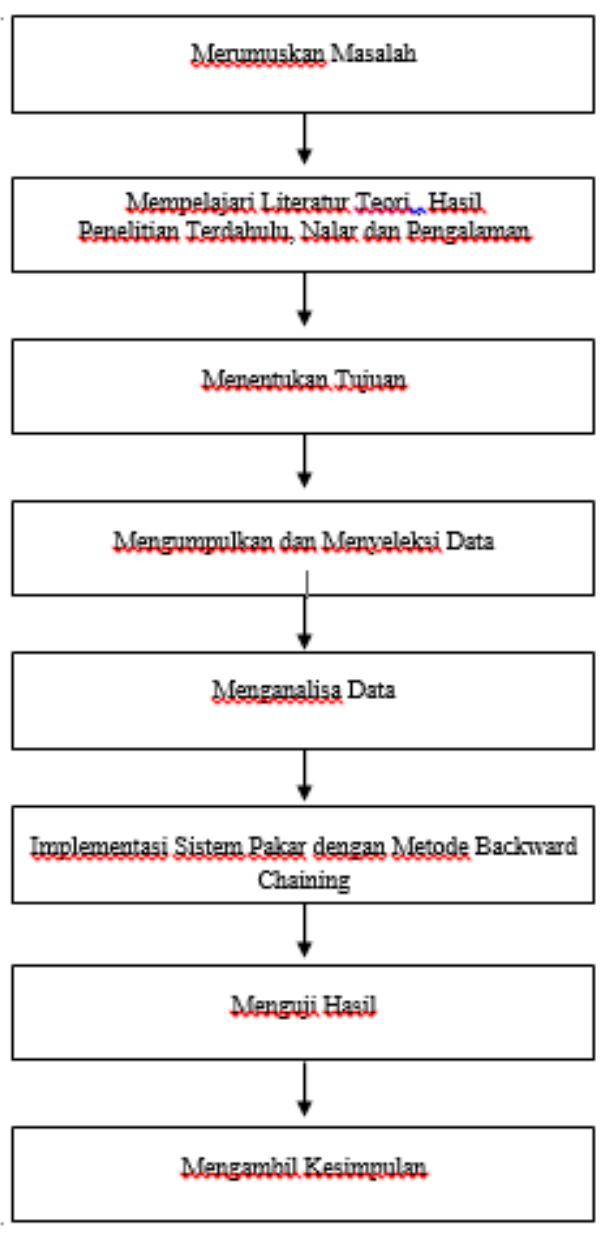

Gambar. 1 Kerangka Kerja Penelitian

Adapun tahapan penelitian yang dilakukan adalah:

\section{Studi Literatur}

Pada tahap ini, dilakukan studi literatur, yaitu dengan mengumpulkan teoriteori yang diperoleh dari bukubuku, artikel, dan karya ilmiah dari internet tentang konsep dan teori dasar sistem pakar dan bagaimana cara kerja metode backward chaining dalam melakukan diagnosis nutrisi yang tepat bagi ibu hamil. 


\section{Pengumpulan Data}

Pada tahap ini, dilakukan proses pegumpulan data yang diperoleh dari wawancara kepada pakar, yaitu dokter kandungan. Data yang dikumpulkan berupa gejala-gejala, jenis-jenis kandungan gizi atau nutrisi yang akan dikumpulkan ke dalam sistem database.

\section{Perancangan}

Pada tahap ini, dilakukan perancangan desain aplikasi sistem pakar untuk mendiagnosis kebutuhan nutrisi atau gizi. Termasuk di dalamnya yaitu perancangan sistem database, membuat tree diagram dan flowchart, perancangan data, dan perancangan antar muka.

\section{Pengkodean}

Pada tahap ini, sistem yang telah dirancang kemudian diimplementasikan ke dalam bentuk coding menggunakan bahasa pemrograman PHP dan database server MySQL. Pada tahap ini juga diterapkan cara kerja algoritma menggunakan metode backward chaining.

\section{Pengujian dan Perbaikan}

Pada tahap ini, akan dilakukan pengujian terhadap sistem yang telah dibangun dengan menggunakan datadata yang telah ada. Hasil pengujian ini kemudiandijadikan dasar untuk membuat perbaikan-perbaikan yang diperlukan untuk menghasilkan sistem seperti yang diharapkan.

\section{Penyusunan Laporan}

Pada tahap ini, dilakukan penyusunan laporan hasil analisis dan perancangan

\section{HASIL DAN PEMBAHASAN \\ Analis Knowledge Base}

Tahap selanjutnya melihat prosedur bidan dalam melakukan pemeriksaan pada ibu hamil untuk memperoleh datanya. Data diambil dari wawancara dan observasi dari para ahli yaitu Klinik Pratama Sarinah dan beberapa orang bidan.

Tabel 1. Gejala Kekurangan Gizi

\begin{tabular}{|l|l|}
\hline \multicolumn{1}{|c|}{ Kode } & \multicolumn{2}{c|}{ Gejala } \\
\hline A1 & Badan mudah lesu, letih, dan cepat capek \\
\hline A2 & Tidak bersemangat \\
\hline A3 & Mudah tersinggung \\
\hline A4 & Stres dan selalu sakit kepala \\
\hline A5 & Suka mengantuk \\
\hline A6 & Berat badan tidak normal \\
\hline A7 & Nafsu makan tidak baik \\
\hline A8 & Buang air besar tidak lancar dan sering terjadi sembelit \\
\hline A9 & Bibir kering dan pecah-pecah \\
\hline A10 & Gusi sering mengalami pendarahan \\
\hline A11 & Adanya kantung mata hitam / gelap \\
\hline A12 & Kaki bengkak. \\
\hline
\end{tabular}

Tabel. 2 Daftar Kandungan Gizi

\begin{tabular}{c|l|}
\hline Kode & \multicolumn{2}{|c|}{ Kandungan Gizi } \\
\hline P1 & Karbohidrat \\
\hline P2 & Protein \\
\hline P3 & Vitamin \\
\hline P4 & Zat Besi \\
\hline P5 & Asam Folat \\
\hline
\end{tabular}

Tabel 3. Tabel Bobot

\begin{tabular}{l|l|c|c|c|c|c|}
\hline Kode & \multicolumn{1}{|c|}{ Gejala } & Karbohidrat & Protein & Vitamin & $\begin{array}{c}\text { Zat } \\
\text { Besi }\end{array}$ & $\begin{array}{c}\text { Asam } \\
\text { Folat }\end{array}$ \\
\hline \hline A1 & $\begin{array}{l}\text { Badan mudah lesu, letih, } \\
\text { dan cepat capek }\end{array}$ & 1 & 1 & 0 & 1 & 0 \\
\hline A2 & Tidak bersemangat & 1 & 1 & 0 & 0 & 1 \\
\hline A3 & Berat badan tidak normal & 1 & 1 & 0 & 0 & 0 \\
\hline A4 & $\begin{array}{l}\text { Stres dan selalu sakit } \\
\text { kepala }\end{array}$ & 0 & 1 & 0 & 1 & 1 \\
\hline A5 & Nafsu makan tidak baik & 0 & 1 & 1 & 0 & 0 \\
\hline A6 & $\begin{array}{l}\text { Adanya kantung mata } \\
\text { hitam/gelap }\end{array}$ & 0 & 1 & 0 & 1 & 0 \\
\hline A7 & Kaki bengkak & 0 & 1 & 1 & 0 & 0 \\
\hline A8 & Mudah tersinggung & 0 & 0 & 0 & 1 & 1 \\
\hline A9 & Suka mengantuk & 0 & 0 & 0 & 1 & \\
\hline A10 & $\begin{array}{l}\text { Buang air besar tidak } \\
\text { lancar dan sering terjadi } \\
\text { sembelit }\end{array}$ & 0 & 0 & 0 & 0 & 1 \\
\hline A11 & $\begin{array}{l}\text { Bibir kering dan pecah- } \\
\text { pecah }\end{array}$ & 0 & 0 & 1 & 0 & 0 \\
\hline A12 & $\begin{array}{l}\text { Gusi sering mengalami } \\
\text { pendarahan }\end{array}$ & 0 & 0 & 1 & 0 & 1 \\
\hline
\end{tabular}

Untuk masing-masing area gejala, terdapat juga 5 aturan kaidah produksi gejala penyakit dalam bentuk IF-THEN rules. Tabel 3.4 berikut ini merupakan 
tabel pembentukan rule dari Sistem Pakar yang akan dibangun:

Tabel 4. Pembentukan Rule

\begin{tabular}{|l|l|l}
\hline \multicolumn{1}{|c|}{ RULE } & \multicolumn{1}{c|}{ IF } & \multicolumn{1}{c}{ THEN } \\
\hline R1 & $\mathrm{A} 1, \mathrm{~A} 2, \mathrm{~A} 3$ & P1 \\
\hline R2 & $\mathrm{A} 1, \mathrm{~A} 2, \mathrm{~A} 3, \mathrm{~A} 4, \mathrm{~A} 5, \mathrm{~A} 6, \mathrm{~A} 7$ & $\mathrm{P} 2$ \\
\hline $\mathrm{R} 3$ & $\mathrm{~A} 5, \mathrm{~A} 7, \mathrm{A1} 1, \mathrm{~A} 12$ & $\mathrm{P} 3$ \\
\hline R4 & $\mathrm{A} 1, \mathrm{~A} 4, \mathrm{~A} 6, \mathrm{~A} 8, \mathrm{~A} 9$ & $\mathrm{P} 4$ \\
\hline R5 & $\mathrm{A} 2, \mathrm{~A} 4, \mathrm{~A} 8, \mathrm{~A} 10, \mathrm{~A} 12$ & $\mathrm{P} 5$ \\
\hline
\end{tabular}

Dari data analisis pengetahuan, selanjutnya data tersebut dibuat dalam bentuk pohon keputusan, seperti gambar 2:

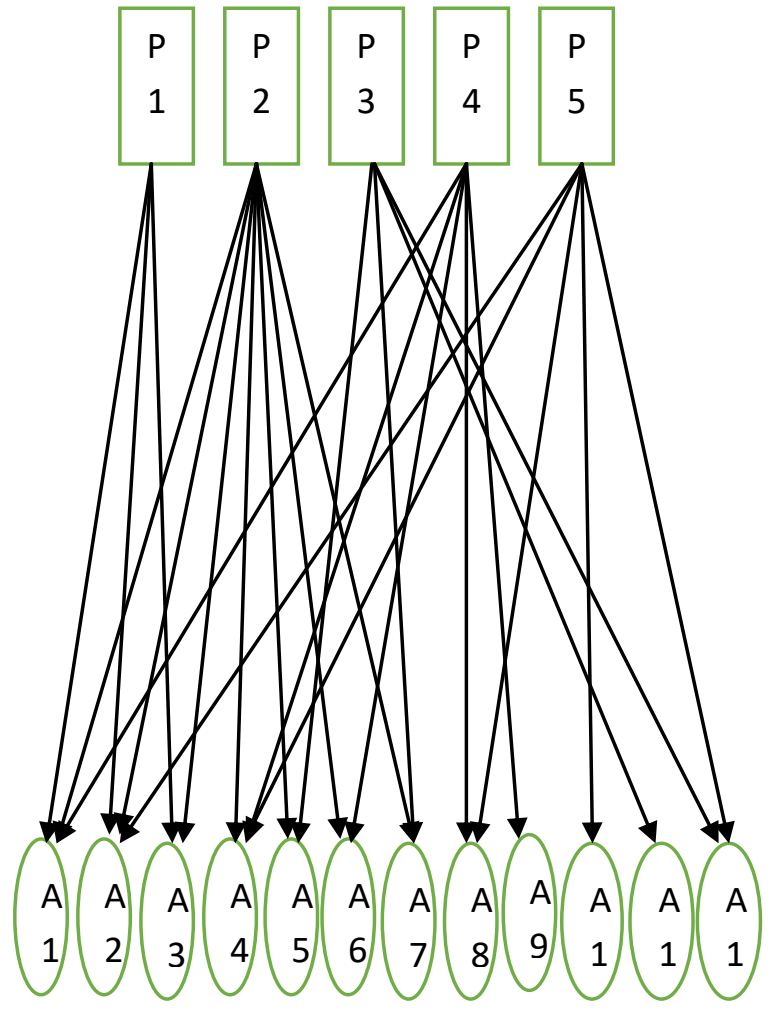

Gambar. 2 Pohon Keputusan Menentukan Nutrisi Yang Tepat Bagi Ibu Hamil

Pada gambar 2 menjelaskan tentang gejala-gejala dari kandungan gizi yang ada, setiap kandungan gizi akan menunjukkan ke gejala-gejala yang sudah ditetapkan seperti P1 = $\mathrm{A} 1, \mathrm{~A} 2, \mathrm{~A} 3$, sesuai dengan bobot yang sudah diberikan pada tabel 3 .

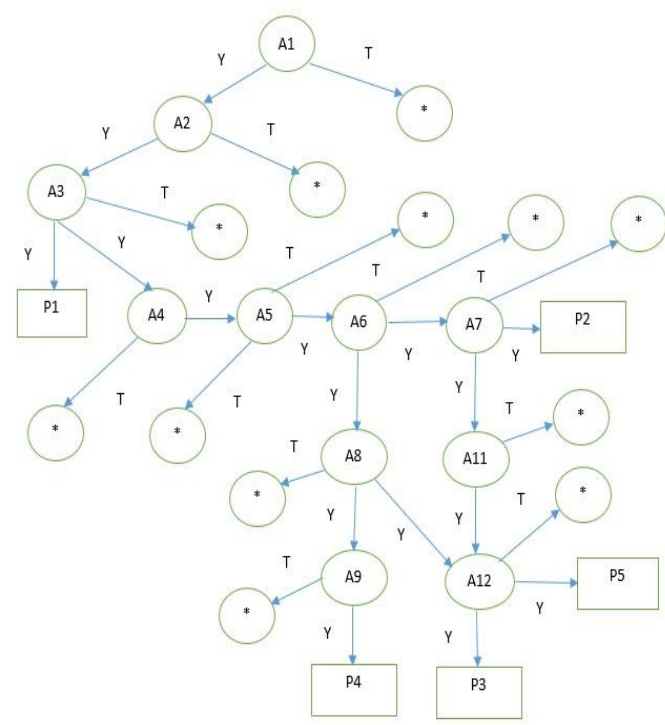

Gambar. 3 Tree Diagram Menentukan Nutrisi yang Tepat Bagi Ibu Hamil

Dari pohon keputusan di atas, didapat rule untuk menentukan gejala kekurangan karbohidrat.

IF kekurangan karbohidrat THEN badan mudah lesu, letih, dan cepat capek $A N D$ tidak bersemangat $A N D$ berat badan tidak normal

\section{Solusi:}

Penyakit :Kekurangan Karbohidrat

Definisi :Seorang wanita selama kehamilan memiliki kebutuhan energi yang meningkat. Energi ini digunakan untuk pertumbuhan janin, pembentukan plasenta, pembuluh darah, jaringan payudara, cadangan lemak, perubahan metabolisme yang terjadi dan pertumbuhan jaringan yang baru. Selain itu, tambahan kalori dibutuhkan sebagai tenaga untuk proses metabolisme jaringan baru. Namun dengan adanya 
pertambahan kebutuhan kalori ini tidak lantas menjadikan ibu hamil terlalu banyak makan. Tubuh ibu hamil memerlukan sekitar 80.000 tambahan kalori pada kehamilan. Dari jumlah tersebut, berarti setiap harinya sekitar 300 tambahan kalori dibutuhkan ibu hamil.

Pilihan Nutrisi :Pilihan yang dianjurkan adalah karbohidrat kompleks seperti roti, serealia, nasi dan pasta.

\section{Backward Chaining}

Konsep Backward Chaining dimulai dari pencarian solusi dari kesimpulan kemudian menelusuri faktafakta yang ada hingga menemukan solusi yang sesuai dengan fakta-fakta yang diberikan oleh user. Dalam menganalisis problem, maka komputer berusaha memenuhi syarat dari posisi "JIKA" pada rule yang konklusinya merupakan goal atau premis dari rule lain. Mesin inferensi mengandung suatu mekanisme pola pikir dan penalaran yang digunakan dalam menyelesaikan suatu masalah, dalam hal ini bagaimana sistem dapat mengambil suatu kesimpulan berdasarkan hasil perbandingan antara input-an user (ibu hamil) dengan nilai normal yang terdapat pada sistem dan antara input-an user terhadap gejala-gejala penyakit yang diderita dengan pengetahuan penyakit yang telah disimpan.

\begin{tabular}{ll}
\hline Rule & IF P1 THEN A1 = TRUE AND \\
1 & $\mathrm{~A} 2=$ TRUE AND A3 = FALSE \\
& AND A4 = FALSE AND A5 = \\
& $F A L S E$ AND A6 = TRUE \\
\hline Rule & IF P2 THEN A1 = TRUE AND \\
2 & $\mathrm{~A} 2=$ TRUE AND A3 = FALSE \\
& AND A4 = TRUE AND A5 = \\
\hline
\end{tabular}

\begin{tabular}{|c|c|}
\hline & $\begin{array}{l}F A L S E \text { AND A6 = TRUE AND } \\
\mathrm{A} 7=\text { TRUE AND A8 = FALSE } \\
A N D \text { A } 9=F A L S E A N D \text { A } 10= \\
F A L S E \text { AND A } 11=\text { TRUE } \\
\text { AND A12 = TRUE }\end{array}$ \\
\hline $\begin{array}{l}\text { Rule } \\
3\end{array}$ & $\begin{array}{l}\text { IF } \mathrm{P} 3 \text { THEN A7 = TRUE AND } \\
\mathrm{A} 8=F A L S E A N D \text { A9 }=\text { TRUE } \\
\text { AND A } 10=\text { TRUE AND A11 } \\
F A L S E A N D \text { A } 12=T R U E\end{array}$ \\
\hline & $\begin{array}{l}I F \mathrm{P} 4 \text { THEN A1 = TRUE AND } \\
\mathrm{A} 2=F A L S E \text { AND } \mathrm{A} 3=\text { TRUE } \\
\text { AND A4 = TRUE AND A5 = } \\
\text { TRUE AND } 66=\text { FALSE AND } \\
\mathrm{A} 7=\text { FALSE AND A8 = } \\
F A L S E A N D \mathrm{~A} 9=F A L S E A N D \\
\mathrm{~A} 10=F A L S E \text { AND A11 } \\
\text { TRUE AND A12=FALSE }\end{array}$ \\
\hline $\begin{array}{l}\text { Rule } \\
5\end{array}$ & 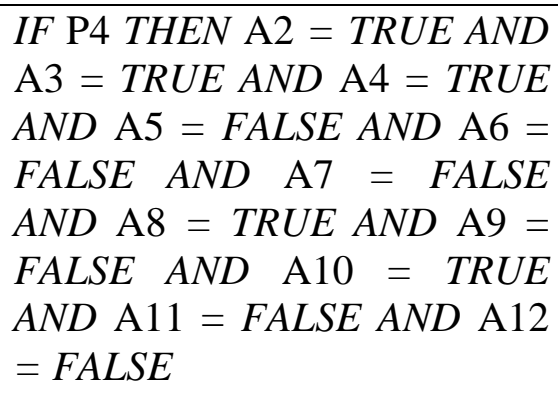 \\
\hline
\end{tabular}

Dengan metode Backward Chaining mendahulukan goal-nya lalu menelusuri gejala tersebut sehingga mendapatkan goal tersebut.

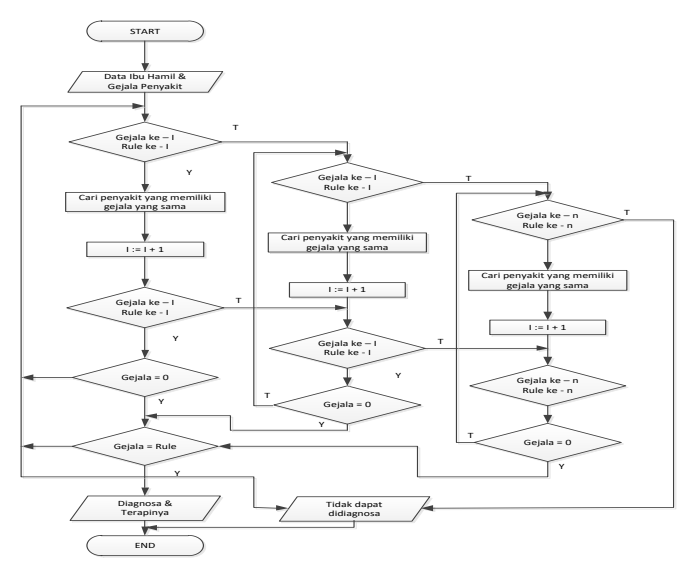

Gambar. 4 Flowchart Mesin Inferensi Backward Chaining 


\section{Design Antarmuka}

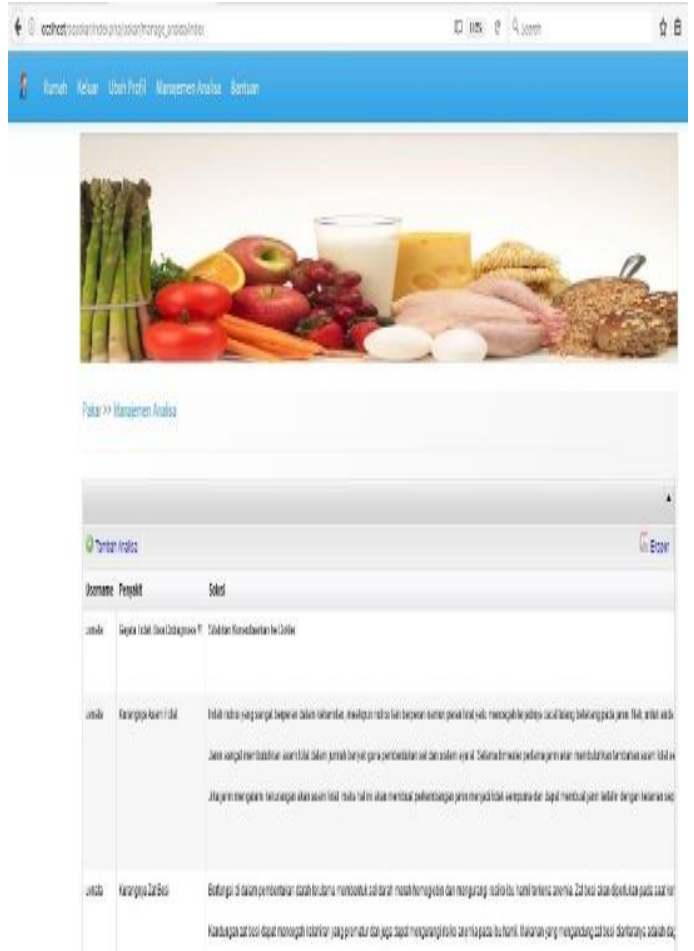

Gambar. 5 Halaman Data Manajemen Analisa
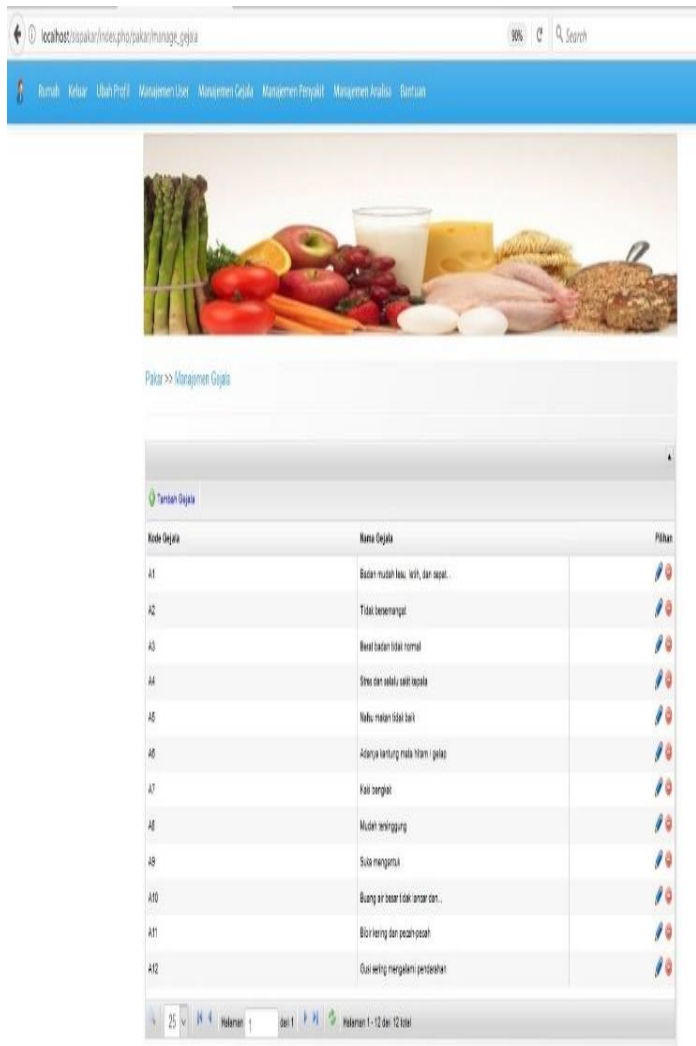

Gambar. 6 Halaman Pilih Gejala

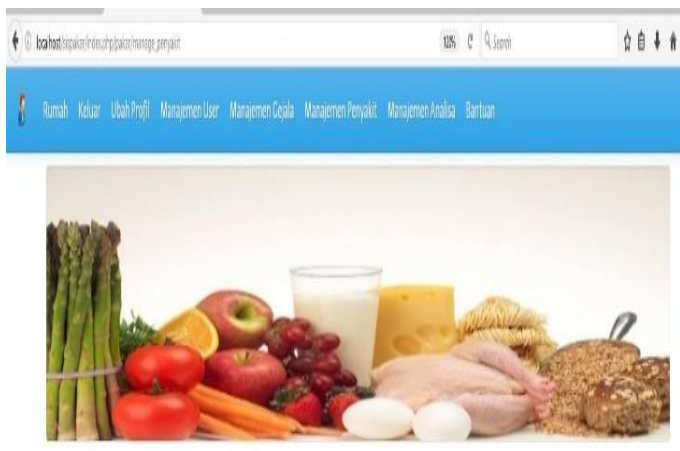

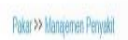

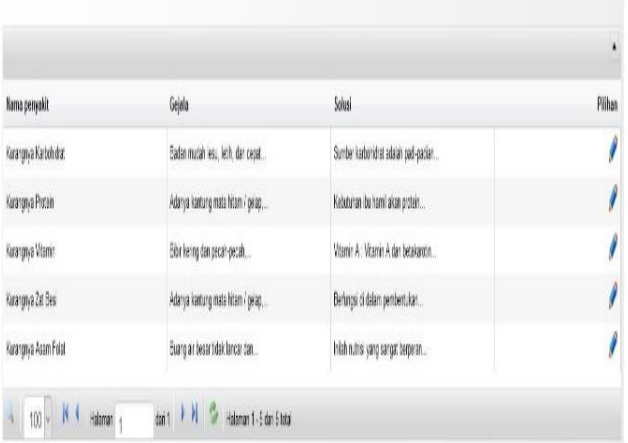

Gambar. 7 Halaman Entri Penyakit dan Solusi
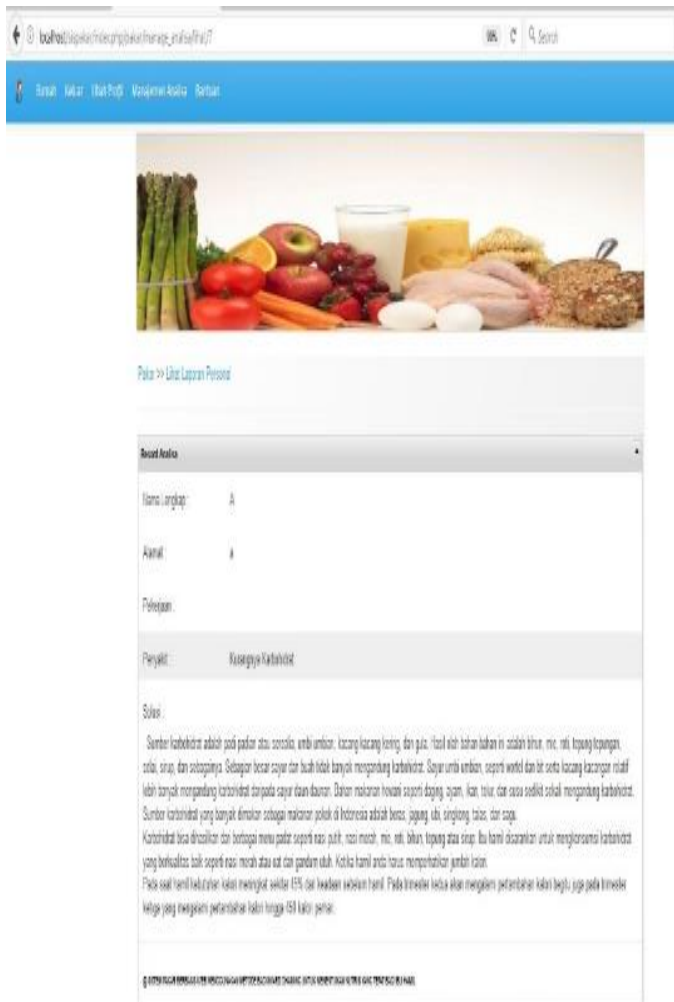

Gambar 8 Halaman Solusi 


\section{SIMPULAN}

Kesimpulan yang dapat diambil dari Sistem Pakar berbasis web menggunakan Backward Chaining dalam menentukan nutrisi yang tepat bagi ibu hamil berdasarkan analisa dan pengujian adalah :

1. Analisa permasalahan nutrisi yang tepat bagi ibu hamil bisa dilakukan dengan baik berdasarkan hasil observasi dan interview dengan pakarnya.

2. Penerapan metoda Backward Chaining dalam menentukan nutrisi yang tepat bagi ibu hamil dapat diterapkan dan menghasilkan solusi yang tepat sesuai dengan gejalagejala yang dipilih.

3. Implementasi metode Backward Chaining berbasis web sudah dapat digunakan untuk mendiagnosa nutrisi yang tepat bagi ibu hamil dan memberikan solusi yang tepat.

\section{DAFTAR PUSTAKA}

Al-Ajlan, A. (2015). The Comparison between Forward and Backward Chaining. International Journal of Machine Learning and Computing, 5(2)

Bahl, N., \& Kapoor, N. (2016). Comparative Study of Forward and Backward Chaining in Artificial Intelligence. International Journal of Engineering And Computer Science, 5(4), 16239-16242

Cantika, Y. E., Witanti, W., \& Renaldi, F. (2016). Sistem Penentuan Komposisi Nutrisi Pakan Sapi Dengan Backward Chaining. Prosiding SNST ke-7 Tahun 2016

Dean, S. V., Lassi, Z. S., Imam, A. S. \& Bhutta, Z. A. (2014). Preconception Care: Nutritional Risks and Interventions. Reproductive Health, 11(3)

Elhissi, J. H., El Sakka, M. A., \& AlKhodari, O. A. (2012). Effect of Maternal Malnutrition on Infant Birth Weight in Gaza Governance. Journal of Al Azhar University Gaza (Natural Sciences), 14, 85-110

Indrawaty, N., \& Putranto, S. J. (2011). Sistem Pakar untuk Mengetahui Pemenuhan Gizi dan Deteksi Awal Kesehatan Ibu Hamil Berbasis Web. 229 Konferensi Nasional Sistem Informasi 2011

Iriani, S. (2015). Penerapan Metode Backward Chaining pada Sistem Pakar Diagnosa Penyakit Tulang Manusia. IJNS - Indonesian Journal on Networking and Security, 4(1) - ijns.apmmi.org

Juriwansyah, I. (2014). Perancangan Aplikasi Web untuk Deteksi Penyakit Paru-Paru dengan Inference Forward Menerapkan. Pelita Informatika Budi Darma, 3(3) 
Mukhtar, N., \& Samsudin. (2014). Sistem Pakar Diagnosa Dampak Penggunaan Softlens Menggunakan Metode Backward Chaining. Jurnal Buana Informatika, 6(1), 21-30

Tarigan, A. F. (2014). Sistem Pakar untuk Mendiagnosa Penyakit Ginjal dengan Metode Backward Chaining. Jurnal TIMES, 3(2), 2529 